\title{
Tritium records to trace groundwater recharge and mixing in western Russian Arctic
}

\author{
ALEXANDER I MALOV \\ N. Laverov Federal Center for Integrated Arctic Research of the \\ UrB of the RAS \\ Presenting Author: malovai@yandex.ru
}

The Arctic regions are characterized by widespread development of permafrost. We studied a sandy aquifer used for water supply in the talik zone of the Pechora River valley (in the western part of the Russian Arctic, extending on the Arctic Ocean coast). In this work, the following tasks are set: i) estimate the concentration of tritium in the groundwater of the region under study and the presence of traces of the "bomb peak", ii) use information on the distribution of tritium to determine the conditions of groundwater recharge; iii) use carbon isotopes to identify old groundwater. It has been found that groundwater has TDS values from $75 \mathrm{mg} / \mathrm{L}$ at a distance from the river to 200 $\mathrm{mg} / \mathrm{L}$ in the coastal zone. Such concentrations are typical for the river waters of the Pechora River during flood and low-water periods, respectively. This indicates a predominantly atmospheric recharge of groundwater at a distance from the river and the participation of river waters in the formation of the composition of groundwater in the coastal zone. According to our estimates, the ${ }^{3} \mathrm{H}$ age of groundwater in onshore wells was 20-25 years, on the basis of which it was concluded that the groundwater that entered the aquifer before 1995-2000 was almost completely replaced. Mean water residence time, sampled from wells remote from the river bank, ranges from 20 to 50 years. However, unlike onshore wells, these groundwaters contain "bomb water" and old water that entered the aquifer before 1952. The age of the old water reaches $12.9 \pm 2.5 \mathrm{ka}$. It was found that with a decrease in the age of groundwater, the value of $\delta^{13} \mathrm{C}$ decreases, and ${ }^{14} \mathrm{C}_{0}$ increases. This may indicate a process of increased carbon exchange between TDIC and soil $\mathrm{CO}_{2}$, caused by thawing permafrost. In connection with the intensive production of hydrocarbons in the Pechora river basin, the composition of river water should be controlled, since river water plays a leading role in the formation of the composition of groundwater used for drinking water supply to settlements in the studied Arctic region.

Acknowledgments

This work was supported by RFBR (projects no. 20-0500045_A). 